\title{
Anti-Proliferative Activity of Launaea fragilis (Asso) Pau and Launaea nudicaulis (L.) Hook.F. Extracts
}

\author{
Salama M El Darier, Sania A Kamal, Ream I Marzouk and Iman H Nour* \\ Botany and Microbiology Department, Faculty of Science, Alexandria University, Egypt
}

*Corresponding author: Iman H Nour, Botany and Microbiology Department, Faculty of Science, Alexandria University,

Alexandria, Egypt

\section{ARTICLE INFO}

Received: 慧April 14, 2021

Published: April 21, 2021

Citation: Salama M El Darier, Sania A Kamal, Ream I Marzouk, Iman H Nour. Anti-Proliferative Activity of Launaea fragilis (Asso) Pau and Launaea nudicaulis (L.) Hook.F. Extracts. Biomed J Sci \& Tech Res 35(2)-2021. BJSTR. MS.ID.005674.

Keywords: Anti-Proliferation; Breast; Colon; Colorectal; Hepatocellular; Launaea fragilis; Launaea nudicaulis; Non-Small Cell Lung; Prostatic

\section{ABSTRACT}

Wild medicinal plants are an efficient source of anticancer agents. The widely distributed Launaea fragilis and Launaea nudicaulis in Egypt were investigated for their anti-proliferative activities against some cancer cell lines. Ethanol extracts of the two species were evaluated in vitro by Sulforhodamine B (SRB) assay on six cell lines; hepatocellular carcinoma (Hep G2), prostatic carcinoma (PC-3), colorectal carcinoma (HCT116), non-small cell lung carcinoma (H1299), breast adenocarcinoma (MCF7) and colon adenocarcinoma (Caco-2). The results showed that the incubation of both L. fragilis and $L$. nudicaulis with non-small cell lung carcinoma (H1299) inhibited significantly the cell proliferation with $\mathrm{IC}_{50}=26.5$ and $20 \mu \mathrm{g} / \mathrm{ml}$, respectively. Launaea fragilis recorded the lowest inhibition values for prostatic carcinoma (PC-3) with $\mathrm{IC}_{50}=40 \mu \mathrm{g} / \mathrm{ml}$. However, breast adenocarcinoma (MCF7) revealed the lowest inhibition value for $L$. nudicaulis with $\mathrm{IC}_{50}=35 \mu \mathrm{g} / \mathrm{ml}$. Ethanol extract of $L$. nudicaulis was more effective in the inhibition of the cell proliferation than that of $L$. fragilis for the six cell lines.

Abbreviations: Caco-2: Colon Adenocarcinoma Cell Line; H1299: Non-Small Cell Lung Carcinoma Cell Line; HCT116: Colorectal Carcinoma Cell Line; Hep G2: Hepatocellular Carcinoma Cell Line; MCF7: Breast Adenocarcinoma Cell Line; PC-3: Prostatic Carcinoma Cell Line; SRB: Sulforhodamine B

\section{Background}

Cancer is a rapid division of abnormal cells which grow beyond their normal limits. Similarly, it can attack adjacent parts of the body and spread to other organs. Lung and breast are the most common cancers (2.09 million cases) followed by colorectal, prostate, skin and stomach in a decreasing order. According to the World Health Organization [1], cancer is the second prominent reason of death globally and it is responsible for an estimated 9.6 million deaths in 2018 and approximately $70 \%$ of mortality occurs in the poor developing countries. Chemotherapeutic agents of cancer possessed toxic side effects on patients, as the cardiac, pulmonary, neurological and renal toxicity, besides to their limited anticancer activities which impeded the conquering of this disease $[2,3]$. Nowadays, there is an increasing demand to discover new anticancer agents that are more selective and less toxic than those currently used [4]. The natural metabolites acted as a repository of various bioactive compounds, which considered a valuable source of anticancer agents [3,5,6]. Launaea Cass. (Asteraceae, Cichorioideae, Cichorieae) is polymorphic and controversial genus with confused intraspecific delimitation. It comprised about 54 species and 10 subspecies distributed in different geographical regions [7]. It had economic values, ecological and ethnobotanical importance [8-10]. Despite the richness of Launaea species with different phenolic compounds such as flavonoids, coumarins and terpenoids [11-14], only limited data was available concerning the anticancer effects of its members.

This study aimed to assess the anti-proliferative activities of $L$. fragilis and L.nudicaulis ethanol extracts throughthe Sulforhodamine B (SRB) assay, in vitro, on six cell lines; hepatocellular carcinoma (Hep G2), prostatic carcinoma (PC-3), colorectal carcinoma (HCT116), non-small cell lung carcinoma (H1299), breast adenocarcinoma (MCF7) and colon adenocarcinoma (Caco-2).

\section{Methods}

Launaea fragilis and L. nudicaulis were collected from their natural habitats in flowering season 2015. The former was gathered from Ras-El-Hikma (N31.19107, E27.78305), El-Gophera village, 180 Km 
Alexandria-Matruh road (N31.05661, E28.08929), El-Dabaa, Alex-Matrouh International coastal road (N31.0291, E28.44343), 150 Km Alexandria-Matruh road (N31.01645, E28.6005), Burg El-ArabEl-Hammam road (N30.94875, E29.50859), Sidi Krir (N31.01733, E29.6339), Abu Qir, Alexandria (N31.32621, E30.06425), as well as Edku and Edku Lake (N31.30612, E30.29934). On the other hand, Launaea nudicaulis was collected from Wadi Halazeen, $45 \mathrm{~km}$ west Matrouh-Salloum road (N31.20902, E26.80541), Wadi Um-Ashtan, Matrouh (N31.27938, E27.0209), 150 Km Alexandria-Matruh road (N31.01645, E28.6005), El-Omayed (N30.83975, E29.28817), Burg El-Arab-El-Hammam road (N30.94875, E29.50859), $97 \mathrm{Km} \mathrm{Al-}$ ex-Cairo road (N30.49128, E30.27832) and 107 Km Alex-Cairo road (N30.4392, E30.34149). Voucher specimens were deposited at Alexandria University Herbarium (ALEX), Egypt. Specimens were investigated and morphologically identified according to Kilian [7] and Boulos [15] at the latter herbarium.

\section{Anti-Proliferative Assay}

A pooled sample was prepared for each species from their aerial parts. Ten grams of powdered sample was macerated in

\section{Results}

\section{Survival Percentage}

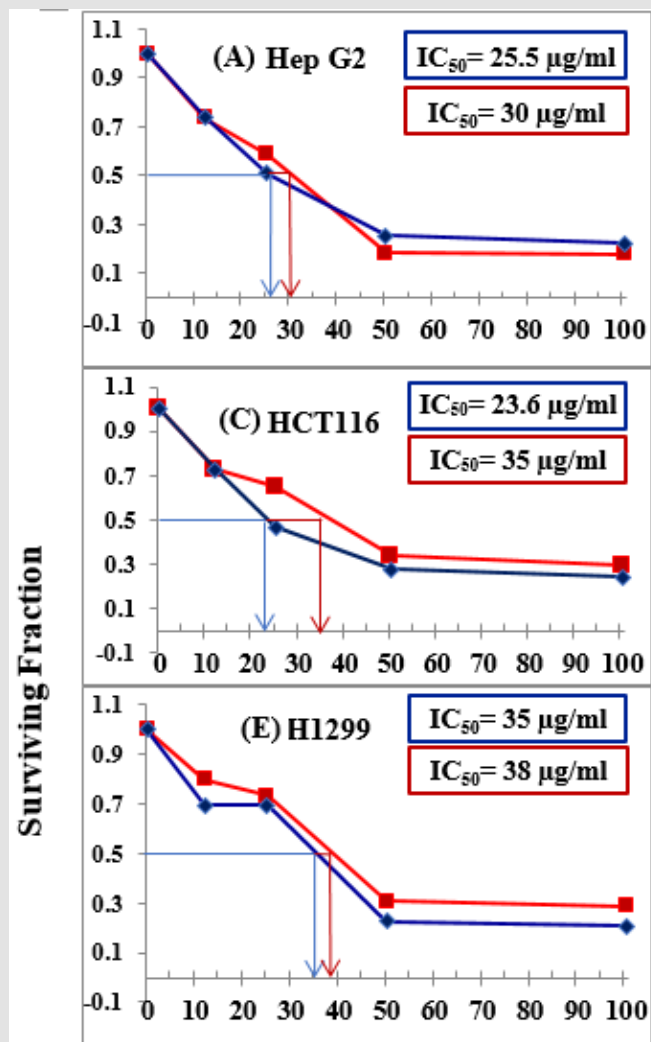

$95 \%$ ethanol $(100 \mathrm{ml})$ for 24 hours at room temperature. The solution was filtered, and the filtrate was evaporated. Extracts were tested at the National Cancer Institute, Cairo, Egypt, by serial subcultures according to Skehan et al. [16]. Surviving fractions of cells throughout extract exposure was characterized graphically by IC50 values. IC50 values were estimated by a linear least-squares regression of the growth values versus the logarithm of the extract concentration; only concentrations that yielded growth values between $10 \%$ and $90 \%$ were used in the calculation. A bar parallel to the $\mathrm{x}$-axis and intersecting the point $50 \%$ on the $\mathrm{y}$-axis was constructed. Also, a bar was plotted parallel to the y-axis that starts from the point of intersection of the bar with the dose-response plot. Therefore, IC50 could then be determined at the point of intersection with the $\mathrm{x}$-axis [16].

\section{Growth Inhibition Percentage (GIP)}

Growth Inhibition Percentage (GIP) was calculated based on Mosmann [17] equation.

$\mathrm{GIP}=[100-($ Treated survival cells /control cells $) \times 100]$

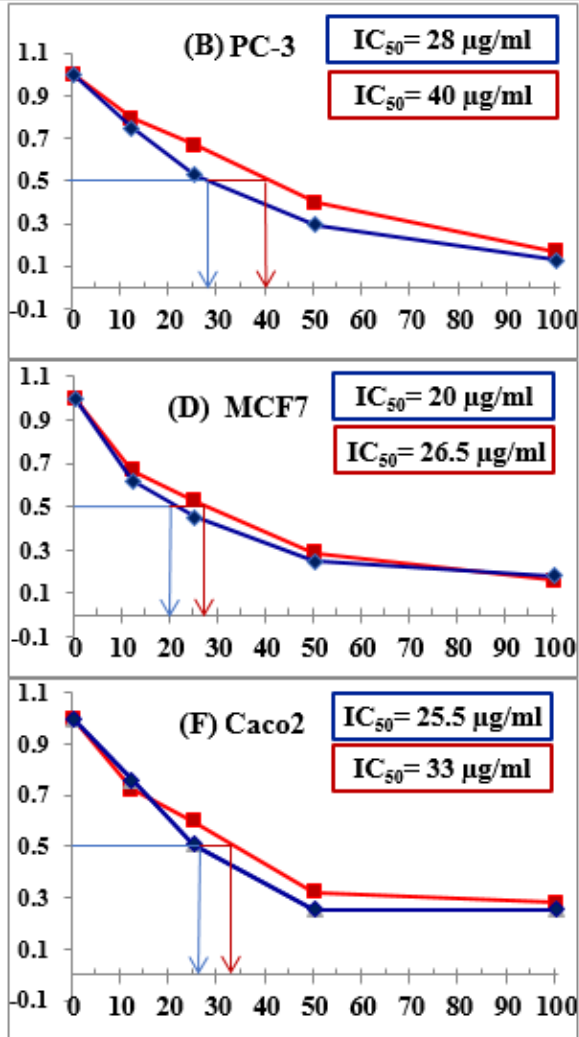

Concentration $\mu \mathrm{g} / \mathrm{ml}$

$\rightarrow$ L. nudicaulis $\rightarrow-$ L. fragilis

Figure 1: Effect of Launaea fragilis and Launaea nudicaulis ethanol shoot extracts on (A)Hep G2; (B)PC-3; (C)HCT116; (D) MCF7; (E)H1299 and (F)Caco2 cell lines. 
Figure 1 represents dose response curves constructed for SRB method between the ranges of $0-100 \mu \mathrm{g} / \mathrm{ml}$. According to the rule that the lower the IC50 value, the stronger the inhibitor, where strong inhibitors are active at lower extract concentrations. Consequently, the obtained results showed that the incubation of L. fragilis with H1299 inhibited significantly the cell proliferation with IC50 $=26.5 \mu \mathrm{g} / \mathrm{ml}$. Subsequently, Hep G2, Caco- 2 and HCT116 cell lines moderately suppressed the cell proliferation with IC50

\section{Growth Inhibition Percentage (GIP)}
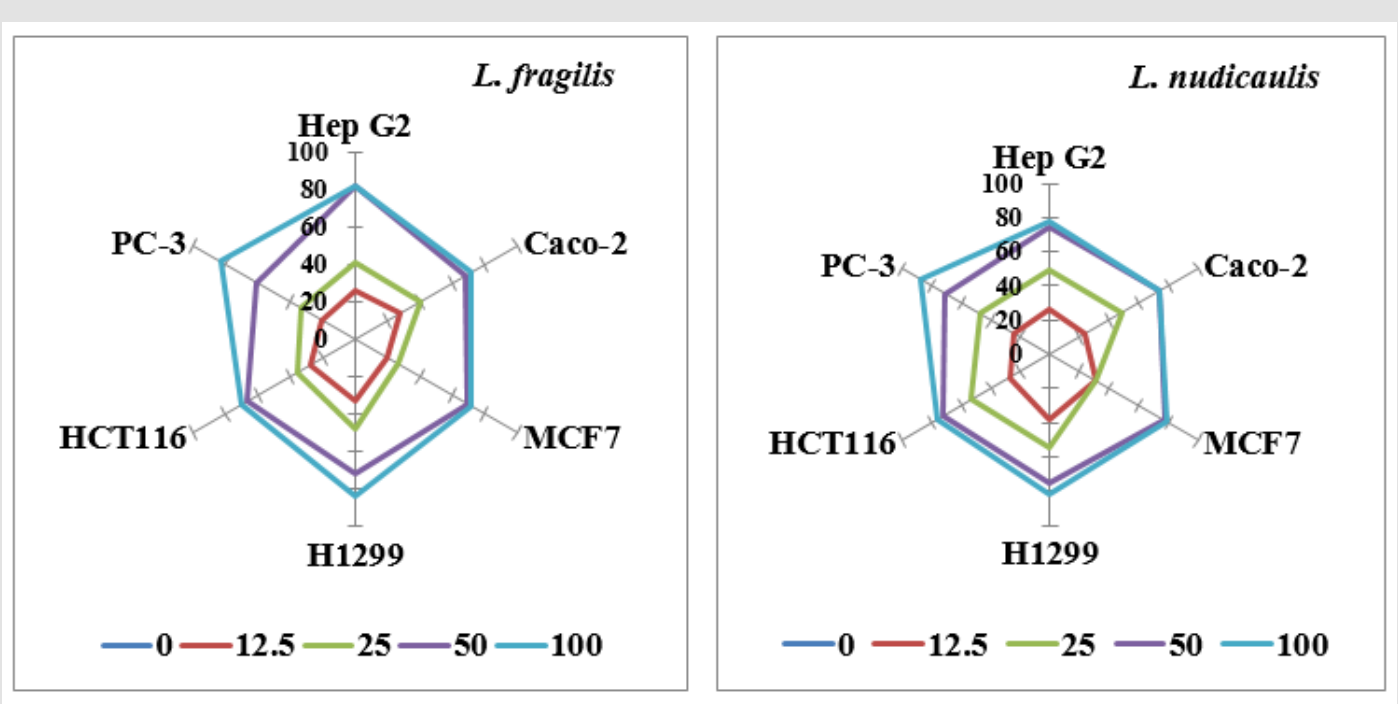

Figure 2: Growth Inhibition Percentage (GIP) of Launaea fragilis and Launaea nudicaulis ethanol shoot extracts against six human cell lines by using five different extract concentrations ( 0 "control", 12.5\%, 25\%, 50\% and 100\%).

GIP is illustrated and statistically represented in Figure 2. The effect of the two extracts was examined as dose-response experiment after 48 hours, at concentrations of $0.0-100 \mu \mathrm{g} / \mathrm{ml}$. It was notable that the inhibition of cancer cells increased with the increase of the extract concentration, although it was noticed that at $100 \%$ extract concentration, the number of inhibited cells is nearly the same or slightly higher than that obtained at $50 \%$ extract concentration. For L. fragilis, the highest inhibition percentage was $81.7 \%$ with Hep G2, while the lowest inhibition percentage was $60.4 \%$ observed for PC-3. Nevertheless, the percentage was in descending order; H1299> MCF7> Caco-2> HCT116 with values were 71.4, 69.4, 68 and 66.3\% respectively. Launaea nudicaulis exhibited the highest inhibition percentage (77.2\%) with MCF7, while, the lowest percentage (70.8\%) was noticed for PC-3. Furthermore, the inhibition percentage was arranged in a decreasing order from H1299, Hep G2, Caco-2 followed by HCT116 cell lines, with values $75.2,74.6,74.4$ and $72.6 \%$ respectively.

\section{Discussion}

Wild medicinal plants present a vast amount of new compounds, which can be used in the modern pharmaceutical research. Nowadays, up to $60 \%$ of the currently used anti-tumorigenic was 30,33 and $35 \mu \mathrm{g} / \mathrm{ml}$, respectively. Nevertheless, MCF7 and PC-3 showed the lowest inhibition values with IC50 were 38 and $40 \mu \mathrm{g} / \mathrm{ml}$, respectively. Alternatively, the incubation of L. nudicaulis with H1299 inhibited successfully the cell proliferation with IC50= $20 \mu \mathrm{g} / \mathrm{ml}$, followed by HCT116 with IC50 $=23.6 \mu \mathrm{g} / \mathrm{ml}$. Both Caco2 and Hep G2 cell lines were suppressed with IC50 $=25.5 \mu \mathrm{g} / \mathrm{ml}$, whereas PC-3 recorded IC50 $=28 \mu \mathrm{g} / \mathrm{ml}$. However, MCF7 revealed the lowest inhibition value with IC $50=35 \mu \mathrm{g} / \mathrm{ml}$. 
Launaea nudicaulis inhibited efficiently the cell proliferation of H1299. Subsequently, HCT116, Caco-2, Hep G2 and PC-3 cell lines exhibit moderate suppression of the cell proliferation, however, MCF7 revealed the lowest inhibition value. This species was traditionally used to treat gastric burns, stomach pain and constipation. Also, it was useful for hemorrhoids, children fever, in addition to the treatment of skin itches and eczema [9]. Similarly, Khan et al. [25] tested the alcoholic extract of Launaea procumbens and reported its significance in the inhibition of the tumor with IC50 $=13 \pm 0.2 \mu \mathrm{g} / \mathrm{mL}$. As well, the methanol extract of Launaea mucronata was evaluated against breast (MCF7), hepatocarcinoma (Hep G2), colon adenocarcinoma (HCT116) and cervix (HeLa) cell lines with IC50 = 12.70, 19.60, 19 and $12.60 \mu \mathrm{g} / \mathrm{ml}$; respectively [26].

\section{Conclusion}

Anti-proliferative effect of $L$. fragilis and L. nudicaulis ethanol extracts can act as bioactive sources of natural anticancer agents. Ethanol extract of L. nudicaulis is more effective in the inhibition of the cell proliferation than that of $L$. fragilis, for the six investigated cell lines. This may be ascribed to the higher antioxidant activity of the former species relative to the latter.

\section{References}

1. (2019) World Health Organization: A report about Cancer.

2. Alonso-Castro AJ, Villarreal ML, Salazar-Olivo LA, Gomez-Sanchez M, Dominguez F, et al. (2011) Mexican medicinal plants used for cancer treatment: pharmacological, phytochemical and ethnobotanical studies. J Ethnopharmacol 133(3): 945-972.

3. Shin SA, Moon SY, Kim WY, Paek SM, Park HH, et al. (2018) Structurebased classification and anti-cancer effects of plant metabolites. Int J Mol Sci 19(9): 2651.

4. Zapata B, Betancur-Galvis L, Duran C, Stashenko E (2014) Cytotoxic activity of Asteraceae and Verbenaceae family essential oils. J Essent Oil Res 26(1): 50-57

5. El-Darier SM, Abdelhady EF (2017) Phytochemistry and cytotoxic activity of Annona squamosa L. fruit pulp against human carcinoma cell lines. Cancer Biol 7(3): 26-30.

6. Roy A, Ahuja S, Bharadvaja N (2017) A review on medicinal plants against cancer. J Plant Sci Agric Res 2(1): 008.

7. Kilian N (1997) Revision of Launaea Cass. (Compositae, Lactuceae, Sonchinae). Englera 17: 1-478.

8. Al-Mahrezi JA, Al-Sabahi JN, Akhtar MS, Selim D, Weli AM (2011) Essential oil composition and antimicrobial screening of Launaea nudicaulis grown in Oman. IJPSR 2(12): 3166-3169.
9. Cheriti A, Belboukhari M, Belboukhari N, Djeradi H (2012) Phytochemical and biological studies on Launaea Cass. genus (Asteraceae) from Algerian Sahara. Curr Top Phytochemistry 11: 67-80.

10. Heneidy SZ, Halmy MW, Bidak LM (2017) The ethnobotanical importance and conservation value of native plants in eastern Arabian Peninsula. Feddes Repert 128(3-4): 105-128.

11. Mansour RM, Ahmed AA, Saleh NA (1983) Flavone glycosides of some Launaea species. Phytochemistry 22(11): 2630-2631.

12. Giner RM, Díaz J, Máñez S, Recio MC, Soriano C, et al. (1992) Phenolics of Spanish Launaea species. Biochem Syst Ecol 20(2): 187-188.

13. Ahmed Z, Ali D, Malik A (2006) Structure determination of ursene-type triterpenes by NMR techniques. Magn Reson Chem 44(7): 717-719.

14. Gherraf N, El-Bassuony AA, Zellagui A, Rhouati S, Ahmed AA, et al. (2006) Isolation of coumarins and coumarin glucoside from Launaea resedifolia. Asian J Chem 18(3): 2348.

15. Boulos L (2009) Flora of Egypt Checklist. Cairo: Al-Hadara Publishing, Egypt pp: 249-252.

16. Skehan P, Storeng R, Scudiero D, Monks A, McMahon J, et al. (1990) New colorimetric cytotoxicity assay for anticancer-drug screening. JNCI: J Natl Cancer Inst 82(13): 1107-1112.

17. Mosmann T (1983) Rapid colorimetric assay for cellular growth and survival: application to proliferation and cytotoxicity assays. J Immunol Methods 65(1-2): 55-63.

18. Da Silva AC, Do Nascimento RM, Do Nascimento Rodrigues DC, Ferreira PM, Pessoa C, et al. (2019) In vitro activity evaluation of seven Brazilian Asteraceae against cancer cells and Leishmania amazonensis. [S Afr J Bot 121: $267-273$

19. Hussain M, Khera RA, Iqbal J, Khalid M, Hanif MA (2019) Phytochemicals: Key to effective anticancer drugs. Mini-Rev Org Chem 16(2): 141-158.

20. Rashid S, Ashraf M, Bibi S, Anjum R (2000) Insecticidal and cytotoxic activities of Launaea nudicaulis (Roxb.) and Launaea resedifolia (Linn.). Pak J Biol Sci 3(5): 808-809.

21. (1979) González GL. Launaea fragilis (Asso) Pau, nombre correcto para L. resedifolia auct. plur. non (L.) Kuntze. Anales Jard Bot Madrid 36: 135138.

22. (1974) Täckholm, V Students' Flora of Egypt. $2^{\text {nd }}$ (Eds.), Cairo University Publishing, Egypt.

23. Belboukhari M, Cheriti A, Belboukhari N (2014) In vitro antioxidant activity of Launaea nudicaulis (Asteraceae) growing in Southwest of Algeria. Ann Sci Technol 6(1): 52-55.

24. El-Sharkawy ER, Ed-Dra AB, Abdallah EM (2017) Phytochemical, antimicrobial and antioxidant properties of Launaea nudicaulis and Farsetia hamiltonii. J Biol Control 31(2): 102-109.

25. Khan RA, Khan MR, Shah NA, Sahreen S, Elahi SN (2016) Antitumor characterization of various fractions of Launaea procumbens. Toxicol Ind Health 32(1): 188-191.

26. El-Sharkawy ER, Mahmoud K (2016) Cytotoxicity of two new coumarin derivatives isolated from Launaea mucronata. Nat Prod Res 30(4): 394398. 
ISSN: 2574-1241

DOI: 10.26717/BJSTR.2021.35.005674

Iman H Nour. Biomed J Sci \& Tech Res

(c) (P) This work is licensed under Creative

Submission Link: https://biomedres.us/submit-manuscript.php

\begin{tabular}{ll} 
BIOMEDICAL & Assets of Publishing with us \\
RESEARCHES & - Global archiving of articles \\
& - Immediate, unrestricted online access \\
\hline - Rigorous Peer Review Process
\end{tabular}

